\title{
Reductive Catalytic Fractionation of Corn Stover Lignin
}

\section{Supporting Information}

Eric M. Anderson, Rui Katahira, Michelle Reed, Michael G. Resch, Eric M. Karp, Gregg T. Beckham*, Yuriy Román-Leshkov*

Page: 10

Tables: 6

Figures: 10 
Table Si shows the compositional analysis of the corn stover used in these studies.

Table S1: compositional analysis results of corn stover

\begin{tabular}{lc}
\hline Component & Wt \% \\
\hline Water & 6.08 \\
Total Ash & 4.39 \\
Structural Inorganics & 2.83 \\
Non-structural inorganics & 1.56 \\
Water Extractable Others & 4.64 \\
Ethanol Extractives & 2.69 \\
Lignin & 13.52 \\
Glucan & 37.36 \\
Xylan & 20.98 \\
Galactan & 1.31 \\
Arabinan & 3.46 \\
Acetyl & 2.17 \\
Total \% & 96.59 \\
\hline
\end{tabular}

Shown below are sample chromatograms from different reaction conditions with each major peak highlighted. Figure S1 displays a typical reaction chromatogram. Figure $\mathrm{S} 2$ shows a $6 \mathrm{~h}$ extraction performed with Ni/C at $250^{\circ} \mathrm{C}$. The sample displayed below was the methanol filtrate obtained directly after removing the residual solids from the reaction slurry. Figure $\mathrm{S}_{3}$ displays lignin oil obtained after a $6 \mathrm{~h}$ extraction with $\mathrm{Ni} / \mathrm{C}$ at $200^{\circ} \mathrm{C}$ with phosphoric acid.

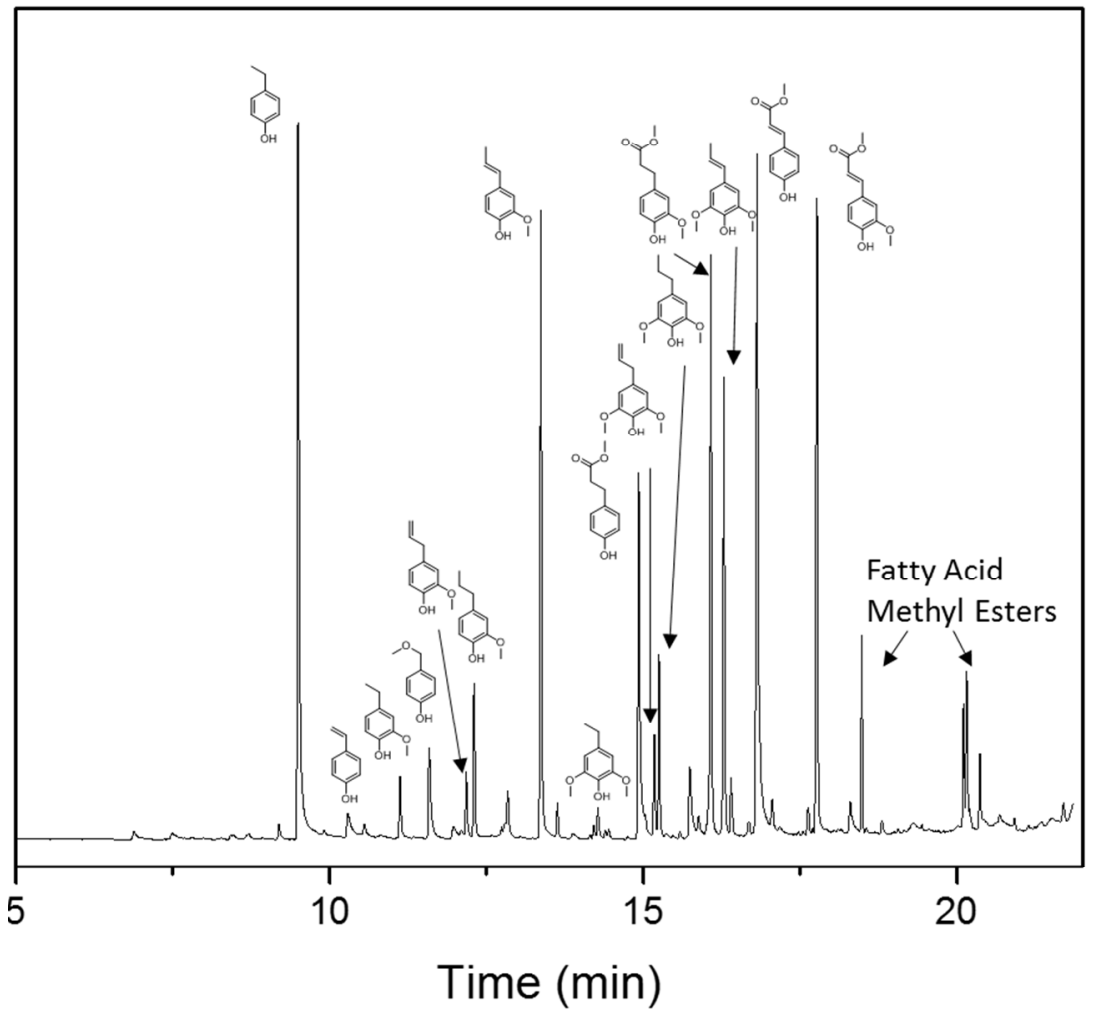

Figure S1: labeled chromatogram at $3 \mathrm{~h}$ with $\mathrm{Ni} / \mathrm{C}$ at $200^{\circ} \mathrm{C}$ 


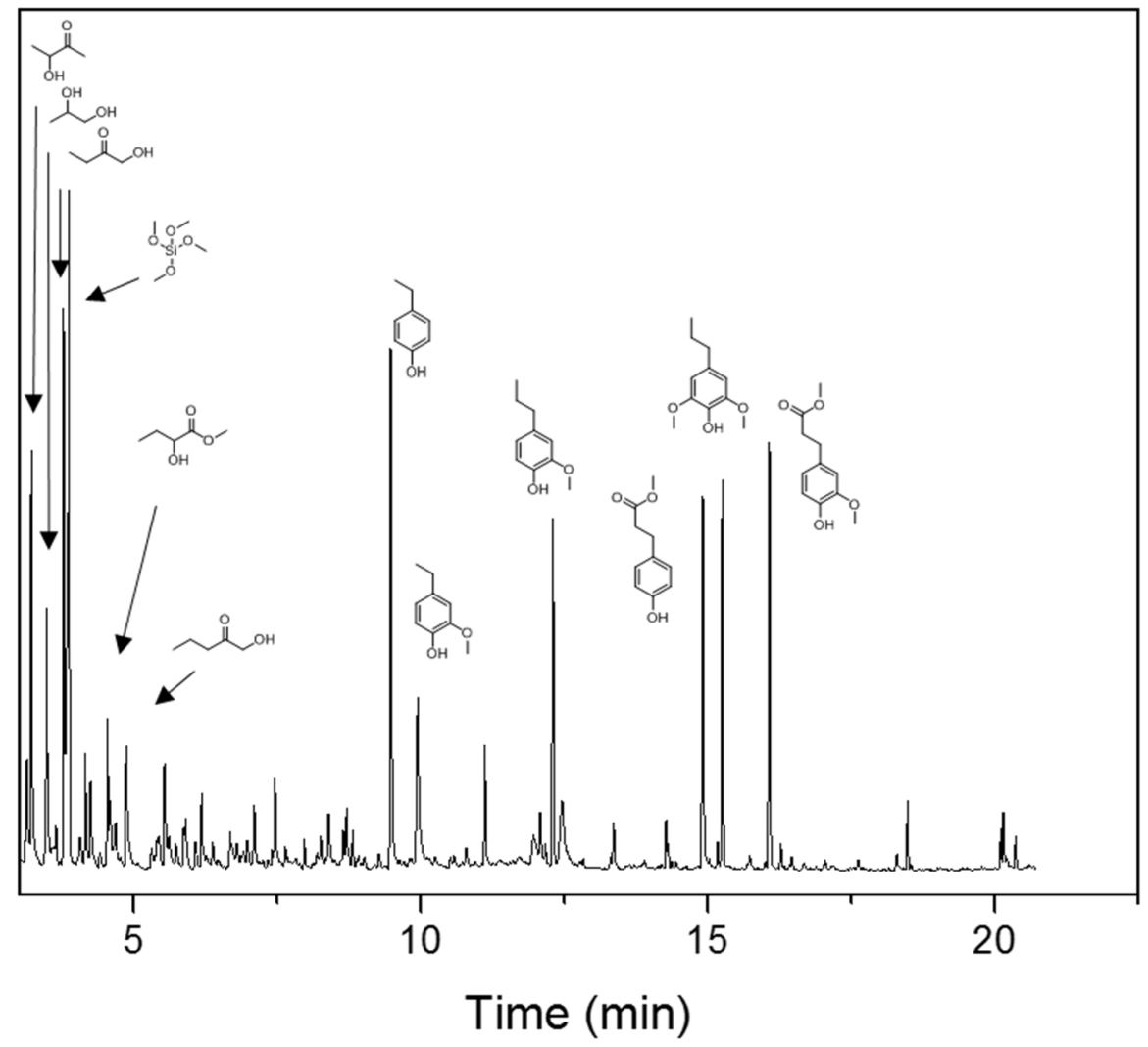

Figure S2: Chromatogram for a $6 \mathrm{~h}$ extraction performed with $\mathrm{Ni} / \mathrm{C}$ at $250^{\circ} \mathrm{C}$ 


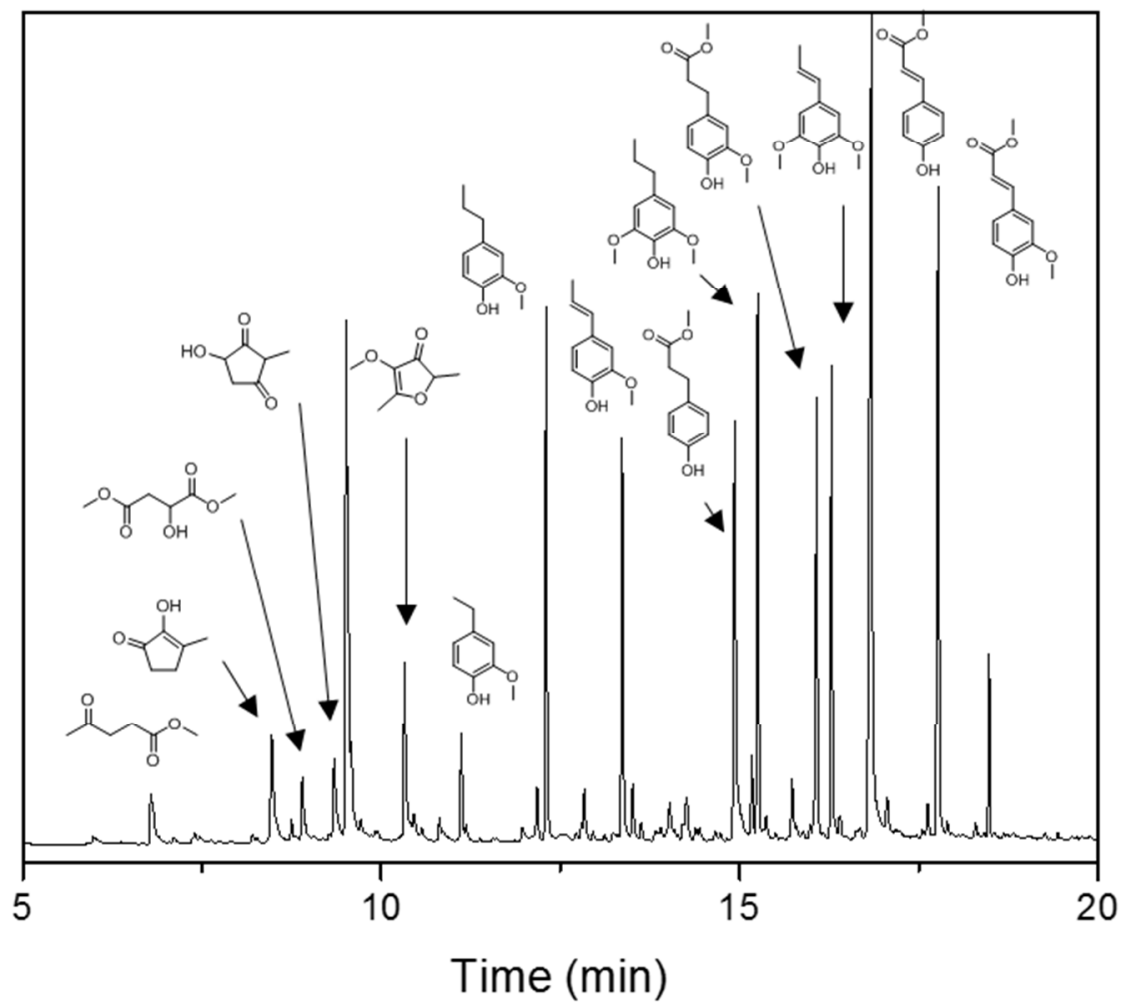

Figure S3: chromatogram from a 6 h extraction with phosphoric acid and $\mathrm{Ni} / \mathrm{C}$ at $200^{\circ} \mathrm{C}$.

Shown below are the monomer yields, oil yields and solids obtained from each extraction. The tables show the main monomer yields as well as the other category for minor products. The other category contains dihydroconiferyl alcohol, dihydrosinapyl alcohol, methyoxypropyl syringol and ethyl syringol.

Table S2: Monomer, oil and solids yields for $200^{\circ} \mathrm{C}$ for $\mathrm{Ni} / \mathrm{C}$ and $\mathrm{Ru} / \mathrm{C}$

\begin{tabular}{|c|c|c|c|c|c|c|c|c|c|c|c|}
\hline Catalyst & $\begin{array}{c}\text { Time } \\
(\mathbf{h})\end{array}$ & $\begin{array}{l}\text { Yield } \\
(w t \%)\end{array}$ & $\begin{array}{c}\text { Ethyl } \\
\text { phenol }\end{array}$ & $\begin{array}{c}\text { Ethyl } \\
\text { guaiacol }\end{array}$ & $\begin{array}{c}\text { Propyl } \\
\text { guaiacol }\end{array}$ & $\begin{array}{c}\text { Methyl } \\
\text { coumarate }\end{array}$ & $\begin{array}{c}\text { Propyl } \\
\text { syringol }\end{array}$ & $\begin{array}{l}\text { Methyl } \\
\text { ferulate }\end{array}$ & Other & $\begin{array}{c}\mathrm{DCM} \\
\text { yield } \\
(\%)\end{array}$ & $\begin{array}{c}\text { Solids } \\
\text { (mg) }\end{array}$ \\
\hline $\mathrm{Ru} / \mathrm{C}$ & 1 & 18.9 & 1.0 & 0.1 & 2.1 & $7 \cdot 7$ & 1.8 & $5 \cdot 3$ & 2.0 & 40 & 715 \\
\hline $\mathrm{Ru} / \mathrm{C}$ & 3 & 25.5 & 1.4 & 0.2 & 2.9 & 10.6 & 2.3 & 6.6 & $3 \cdot 3$ & 51 & 707 \\
\hline $\mathrm{Ru} / \mathrm{C}$ & 6 & 22.2 & 1.0 & 0.1 & 2.4 & 9.7 & 1.8 & $5 \cdot 9$ & 2.9 & 55 & 693 \\
\hline $\mathrm{Ru} / \mathrm{C}$ & 24 & 28.0 & 2.7 & 0.3 & 4.0 & 8.5 & 4.6 & 7.8 & 0.2 & 55 & 662 \\
\hline $\mathrm{Ni} / \mathrm{C}$ & 1 & 21.3 & 2.4 & 0.1 & 3.1 & 6.2 & 2.3 & 6.2 & 1.1 & 37 & 755 \\
\hline $\mathrm{Ni} / \mathrm{C}$ & 3 & 24.5 & 2.6 & 0.1 & 3.4 & 8.7 & 2.5 & 7.2 & 0.3 & 49 & 764 \\
\hline $\mathrm{Ni} / \mathrm{C}$ & 6 & 28.3 & 3.6 & 0.4 & 3.8 & 9.1 & $3 \cdot 4$ & 7.8 & 0.2 & 58 & 723 \\
\hline $\mathrm{Ni} / \mathrm{C}$ & 24 & 28.6 & 3.8 & 0.5 & 3.8 & 8.7 & 3.7 & 8.2 & 0 & 59 & 730 \\
\hline
\end{tabular}

Table S3: Monomer, oil and solids yield for $250^{\circ} \mathrm{C}$ extractions with $\mathrm{Ni} / \mathrm{C}$ and $\mathrm{Ru} / \mathrm{C}$

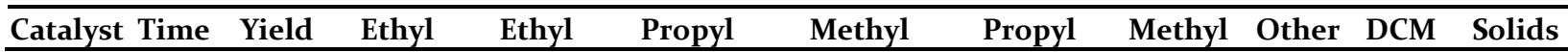




\begin{tabular}{|c|c|c|c|c|c|c|c|c|c|c|c|}
\hline & (h) & $(w t \%)$ & phenol & guaiacol & guaiacol & coumarate & syringol & ferulate & & $\begin{array}{c}\text { yield } \\
(\%)\end{array}$ & (mg) \\
\hline $\mathrm{Ru} / \mathrm{C}$ & 1 & 28.8 & 1.8 & 0.5 & 2.9 & 10.8 & 3.0 & 7.1 & 2.8 & 65 & 590 \\
\hline $\mathrm{Ru} / \mathrm{C}$ & 3 & 32.2 & 2.2 & 0.7 & 3.2 & 11.1 & 3.6 & 7.8 & $5 \cdot 7$ & 93 & 498 \\
\hline $\mathrm{Ru} / \mathrm{C}$ & 6 & 29.0 & 2.6 & 0.8 & 3.1 & 8.8 & 3.2 & 7.0 & $5 \cdot 5$ & 102 & 256 \\
\hline $\mathrm{Ni} / \mathrm{C}$ & 1 & 25.6 & 3.8 & 0.5 & 3.6 & 7.0 & 3.4 & 6.8 & 0.6 & 66 & 626 \\
\hline $\mathrm{Ni} / \mathrm{C}$ & 3 & 28.6 & $4 \cdot 7$ & 0.9 & 4.2 & 7.0 & 3.8 & $7 \cdot 4$ & 0.7 & 73 & $5^{21}$ \\
\hline $\mathrm{Ni} / \mathrm{C}$ & 6 & 27.2 & 4.5 & 0.9 & 3.8 & $7 \cdot 3$ & 3.2 & 7.2 & 0.4 & 102 & 379 \\
\hline
\end{tabular}

Table S4: Monomers, oils and solids yields for extractions performed with an acid co-catalyst.

\begin{tabular}{|c|c|c|c|c|c|c|c|c|c|c|c|}
\hline Catalyst & $\begin{array}{c}\text { Time } \\
\text { (h) }\end{array}$ & $\begin{array}{l}\text { Yield } \\
(w t \%)\end{array}$ & $\begin{array}{c}\text { Ethyl } \\
\text { phenol }\end{array}$ & $\begin{array}{c}\text { Ethyl } \\
\text { guaiacol }\end{array}$ & $\begin{array}{c}\text { Propyl } \\
\text { guaiacol }\end{array}$ & $\begin{array}{c}\text { Methyl } \\
\text { coumarate }\end{array}$ & $\begin{array}{c}\text { Propyl } \\
\text { syringol }\end{array}$ & $\begin{array}{c}\text { Methyl } \\
\text { ferulate }\end{array}$ & Other & $\begin{array}{c}\text { DCM } \\
\text { yield } \\
(\%)\end{array}$ & $\begin{array}{c}\text { Solids } \\
\text { (mg) }\end{array}$ \\
\hline $\begin{array}{c}\mathrm{Ni} / \mathrm{C} \\
\left(\mathrm{H}_{3} \mathrm{PO}\right)\end{array}$ & 1 & 22.7 & 1.9 & 0.2 & $5 \cdot 3$ & 6.8 & $4 \cdot 3$ & 4.2 & 0.1 & 68 & 524 \\
\hline $\begin{array}{c}\mathrm{Ni} / \mathrm{C} \\
\left(\mathrm{H} \mathrm{PO}_{3}\right)\end{array}$ & 3 & 31.9 & 2.4 & 0.3 & $4 \cdot 9$ & 12.3 & 4.4 & $7 \cdot 7$ & 0.1 & 97 & 439 \\
\hline $\begin{array}{c}\mathrm{Ni} / \mathrm{C} \\
\left(\mathrm{H} \mathrm{PO}_{3}\right)\end{array}$ & 6 & $37 \cdot 9$ & 3.6 & 0.4 & 5.1 & 14.4 & $4 \cdot 7$ & 9.1 & 0.7 & 130 & 394 \\
\hline $\begin{array}{l}\mathrm{Ni} / \mathrm{C} \\
(\mathrm{H}+)\end{array}$ & 1 & 18.9 & 1.2 & 0.4 & 2.1 & 6.3 & 1.3 & 6.4 & 0.8 & 34 & 726 \\
\hline $\begin{array}{l}\mathrm{Ni} / \mathrm{C} \\
(\mathrm{H}+)\end{array}$ & 3 & 26.4 & 2.9 & 0.2 & 3.4 & 8.9 & 3.1 & $7 \cdot 4$ & 0.6 & 50 & 721 \\
\hline $\begin{array}{l}\mathrm{Ni} / \mathrm{C} \\
(\mathrm{H}+)\end{array}$ & 6 & 31.9 & 3.9 & 0.4 & 4.2 & 10.4 & $4 \cdot 3$ & 8.5 & 0.3 & 54 & 691 \\
\hline
\end{tabular}

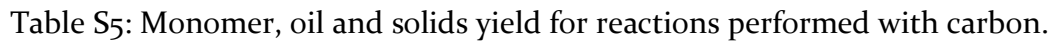

\begin{tabular}{|c|c|c|c|c|c|c|c|c|c|c|}
\hline Catalyst & $\begin{array}{l}\text { Yield } \\
(w t \%)\end{array}$ & $\begin{array}{c}\text { Ethyl } \\
\text { phenol }\end{array}$ & $\begin{array}{c}\text { Ethyl } \\
\text { guaiacol }\end{array}$ & $\begin{array}{c}\text { Propyl } \\
\text { guaiacol }\end{array}$ & $\begin{array}{c}\text { Methyl } \\
\text { coumarate }\end{array}$ & $\begin{array}{l}\text { Propyl } \\
\text { syringol }\end{array}$ & $\begin{array}{l}\text { Methyl } \\
\text { ferulate }\end{array}$ & Other & $\begin{array}{c}\text { DCM } \\
\text { yield } \\
(\%)\end{array}$ & $\begin{array}{c}\text { Solids } \\
\text { (mg) }\end{array}$ \\
\hline$C$ & $15 \cdot 3$ & 0.5 & o & 0.5 & 6.1 & 0.3 & $5 \cdot 5$ & 2.5 & 46 & 739 \\
\hline $\begin{array}{c}\mathrm{C} \\
(\mathrm{H}+)\end{array}$ & 17.0 & 1.0 & o & 0.4 & $7 \cdot 4$ & 0.4 & $5 \cdot 9$ & 1.9 & 50 & 724 \\
\hline $\begin{array}{c}\mathrm{C} \\
\left(\mathrm{H} \mathrm{PO}_{3}{ }_{4}\right)\end{array}$ & 16.4 & o & o & 0.3 & 9.6 & 0.3 & $5 \cdot 4$ & 0.8 & 89 & 475 \\
\hline $\begin{array}{c}C \\
(250 \mathrm{C}) \\
\end{array}$ & 16.5 & 2.7 & 1.5 & 1.2 & 4.4 & 0.4 & $5 \cdot 7$ & 0.6 & 89 & $45^{1}$ \\
\hline
\end{tabular}

The GPC results for $250^{\circ} \mathrm{C}$ extractions with $\mathrm{Ni} / \mathrm{C}$ and $\mathrm{Ru} / \mathrm{C}$ are shown in figure $\mathrm{S}_{4}$ below. 

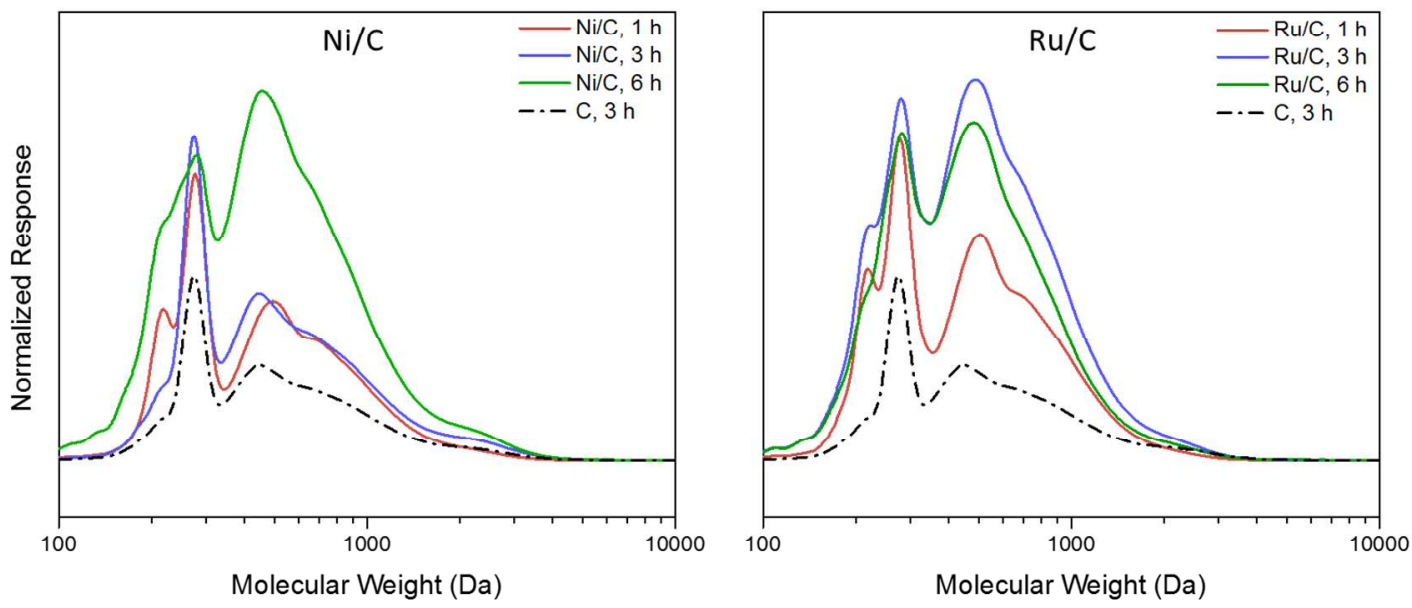

Figure $\mathrm{S}_{4}$ : GPC results for extractions performed at $250^{\circ} \mathrm{C}$ with $\mathrm{Ni} / \mathrm{C}$ and $\mathrm{Ru} / \mathrm{C}$

Six replicate extractions were performed to assess the reproducibility of the RCF process. Shown in table S6 are the individual monomer yields, oil mass, and solid masses obtained after each extraction. The monomer yields vary slightly for each individual product obtained but the total yields are consistent. The oil yields were also consistent between runs. The solids yields are much more variable and likely arose due to loss of material in the drying process which was performed in weight boats in a fume hood.

Table S6: replicate 3 h extractions performed with $\mathrm{Ni} / \mathrm{C}(\mathrm{H}+)$ at $200^{\circ} \mathrm{C}$

\begin{tabular}{|c|c|c|c|c|c|c|}
\hline Run & 1 & 2 & 3 & 4 & 5 & 6 \\
\hline Ethyl phenol & 2.8 & 2.8 & 2.8 & 3.1 & $3 \cdot 3$ & 2.4 \\
\hline Ethyl guaiacol & 0.2 & 0.2 & 0.2 & 0.2 & 0.3 & 0.1 \\
\hline Propyl guaiacol & 3.2 & 3.6 & 3.6 & 3.4 & $3 \cdot 3$ & 3.2 \\
\hline Methyl coumarate & $9 \cdot 3$ & 8.9 & 8.5 & 9.2 & 8.4 & 9.0 \\
\hline Propyl syringol & 3.0 & $3 \cdot 3$ & 3.6 & 3.2 & 3.0 & 2.3 \\
\hline Methyl ferulate & 7.0 & 7.2 & 7.0 & 7.8 & $7 \cdot 3$ & 8.1 \\
\hline Other & 0.5 & 0.6 & 0.5 & 0.6 & 0.6 & 0.6 \\
\hline Total monomers & 26.0 & 26.6 & 26.1 & 27.4 & 26.2 & 25.8 \\
\hline Solids (mg) & $\mathrm{X}$ & 667.2 & 600.8 & 723.2 & 717.5 & 722.8 \\
\hline Oil (mg) & 72.4 & $69 \cdot 5$ & 68.2 & 64.5 & 63.8 & 72.3 \\
\hline
\end{tabular}




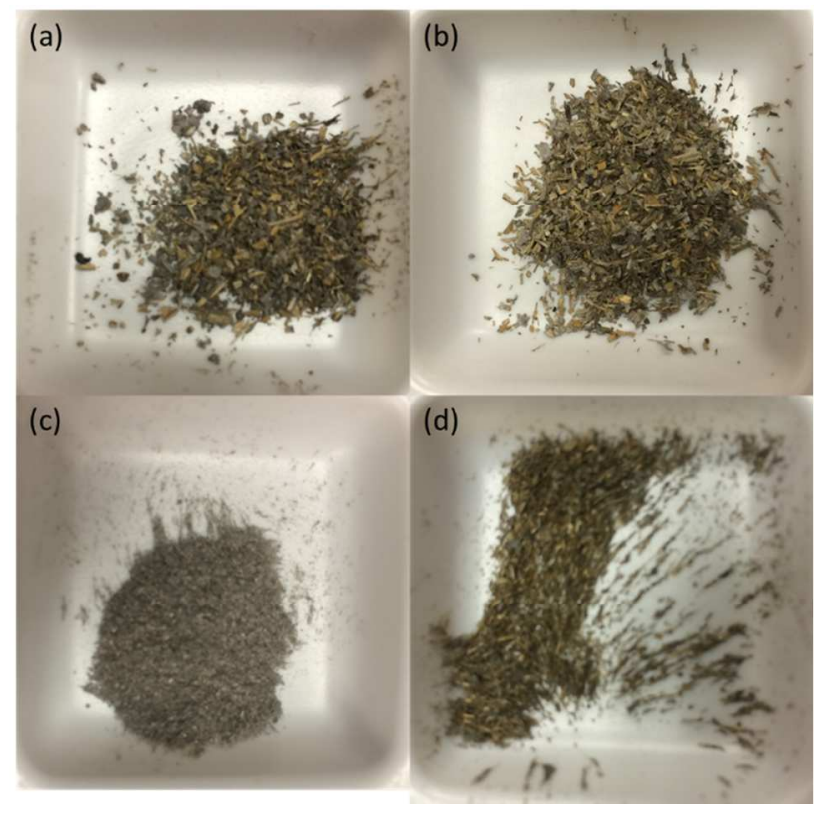

Figure S5: residual solids after a $6 \mathrm{~h}$ RCF treatment. Panel (a) solids after treatment with Ni/C at $200^{\circ} \mathrm{C}$. Panel (b) solids after treatment with $\mathrm{Ni} / \mathrm{C}(\mathrm{H}+)$ at $200^{\circ} \mathrm{C}$. Panel (c) solids after treatment with $\mathrm{Ni} / \mathrm{C}$ and phosphoric acid at $200^{\circ} \mathrm{C}$. Panel (d) solids after treatment with $\mathrm{Ni} / \mathrm{C}$ at $250^{\circ} \mathrm{C}$.

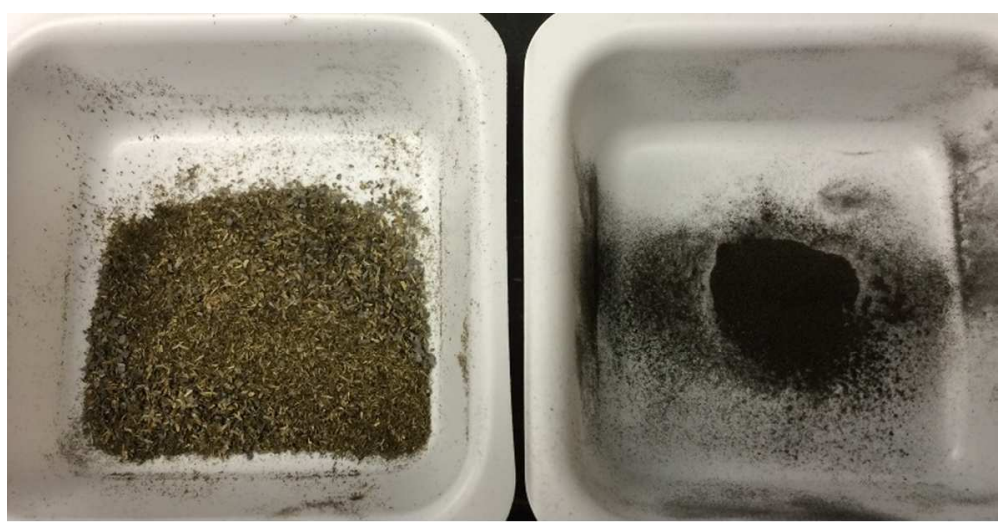

Figure S6: residual solids and catalyst separated with a $107 \mu \mathrm{m}$ sieve.

Synthesis of model compounds: methyl coumarate was synthesized from 4-hydroxycinnamic acid (Sigma-Aldrich, predominately trans isomer). 1.0133 was dissolved in $100 \mathrm{~mL}$ of methanol. $0.6221 \mathrm{~g}$ of $35 \mathrm{wt} \%$ hydrochloric acid was added and the solution was refluxed for 1 hour. The reaction was cooled to room temperature and sodium bicarbonate was added until the solution stopped bubbling. The slurry was filtered to remove excess sodium bicarbonate. The methanol was removed by vacuum evaporation to yield $1.35 \mathrm{~g}$ of crude solid. $0.5309 \mathrm{~g}$ of the solid was dissolved in $10 \mathrm{~mL}$ of methanol. $22 \mathrm{~mL}$ of deionized water was added and the solution was cooled to $\mathrm{o}^{\circ} \mathrm{C}$. The slurry was filtered and the resulting cake was washed with $10 \mathrm{~mL}$ deionized water to yield $0.260 \mathrm{~g}$ of methyl coumarate. The purity of the compound was checked by GC-MS and ${ }^{1} \mathrm{H}$ NMR. GC-MS and ${ }^{1} \mathrm{H}$ NMR indicated only one impurity, the cis isomer which was determined to be $\sim 18 \mathrm{~mol} \%$ by ${ }^{1} \mathrm{H}$ NMR. ${ }^{1} \mathrm{H}$ NMR $\left(400 \mathrm{MHz}, \mathrm{MeOH}-\mathrm{d}_{4}\right) \delta(\mathrm{ppm}): 7.61(\mathrm{~d}, 1 \mathrm{H}), 7.45(\mathrm{~s}, 2 \mathrm{H}), 6.81(\mathrm{~d}$, $2 \mathrm{H}), 6.32(\mathrm{~d}, 1 \mathrm{H}), 3.76(\mathrm{~s}, 3 \mathrm{H})$ 
Methyl ferulate was synthesized from ferulic acid. $1.012 \mathrm{~g}$ of ferulic acid was dissolved in $100 \mathrm{~mL}$ of methanol. $0.6242 \mathrm{~g}$ of $35 \mathrm{wt} \%$ hydrochloric acid was added and the solution was refluxed for 1 hour. The excess acid was neutralized with sodium bicarbonate until bubbling no longer persisted. The slurry was filtered to remove the partially insoluble base. The methanol was removed to yield a light tan oil with some residual sodium bicarbonate. The products were dissolved in $20 \mathrm{~mL}$ water and $10 \mathrm{~mL}$ DCM. The aqueous layer was extracted 2 times with $10 \mathrm{~mL}$ of DCM. The organic fractions were combined and the solvent was removed to yield o.780 g of a light tan oil. A methyl ether impurity was observed by both NMR and GS/MS and determined to be at $5 \mathrm{~mol} \%$ in the oil. Additionally, the cis isomer of methyl ferulate was also observed at $13 \mathrm{~mol} \%$. ${ }^{1} \mathrm{H}$ NMR $\left(400 \mathrm{MHz}, \mathrm{MeOH}-\mathrm{d}_{4}\right) \delta(\mathrm{ppm}): 7.49(\mathrm{~d}, 1 \mathrm{H}), 7.04(\mathrm{~s}, 1 \mathrm{H}), 6.94(\mathrm{~d}, 1 \mathrm{H}), 6.79(\mathrm{~d}, 1 \mathrm{H})$, $6.24(\mathrm{~d}, 1 \mathrm{H}), 3.80(\mathrm{~s}, 3 \mathrm{H}), 3.70(\mathrm{~s}, 3 \mathrm{H})$

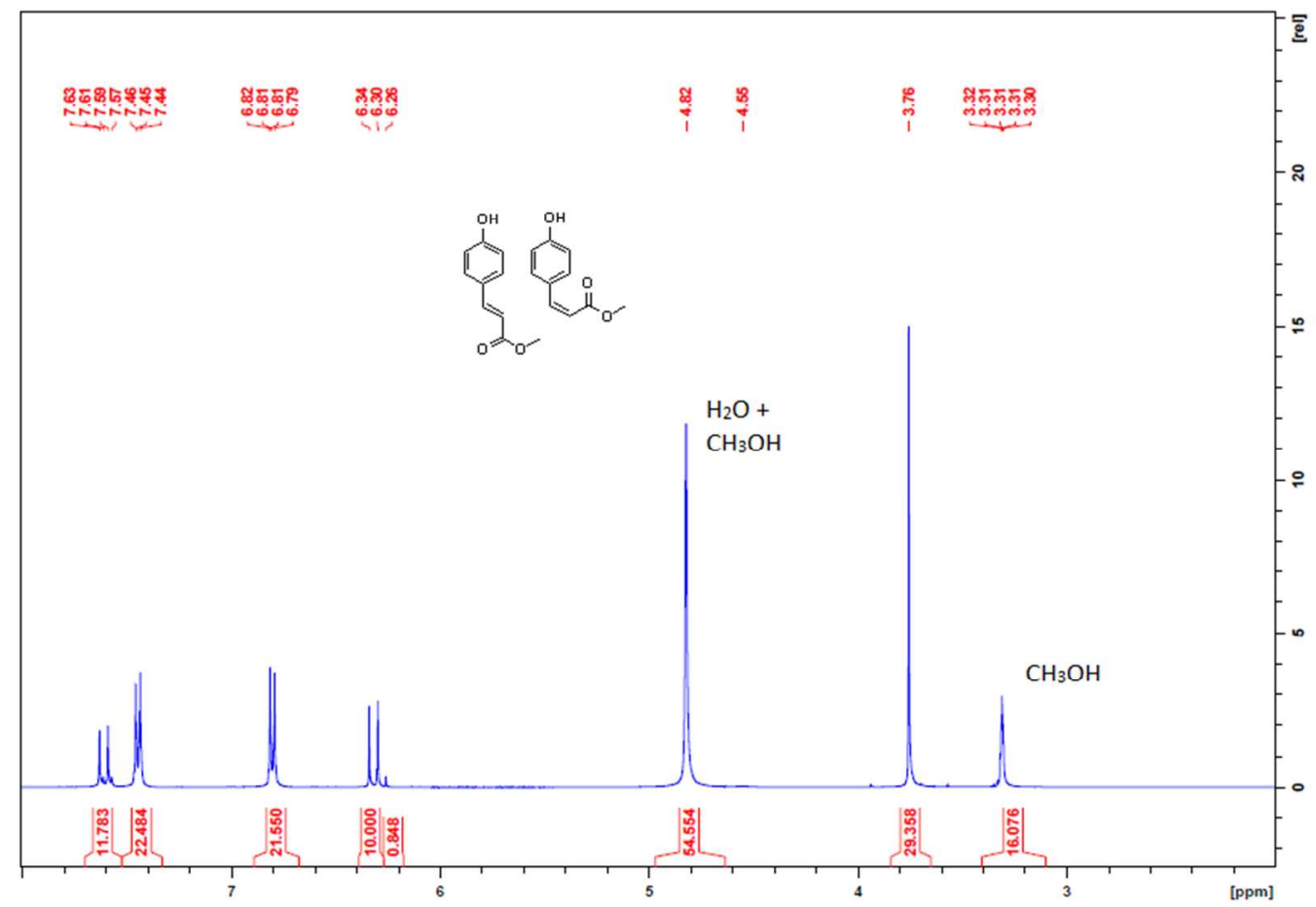

Figure $S_{7}$ : $1 H$ NMR of methyl coumarate 


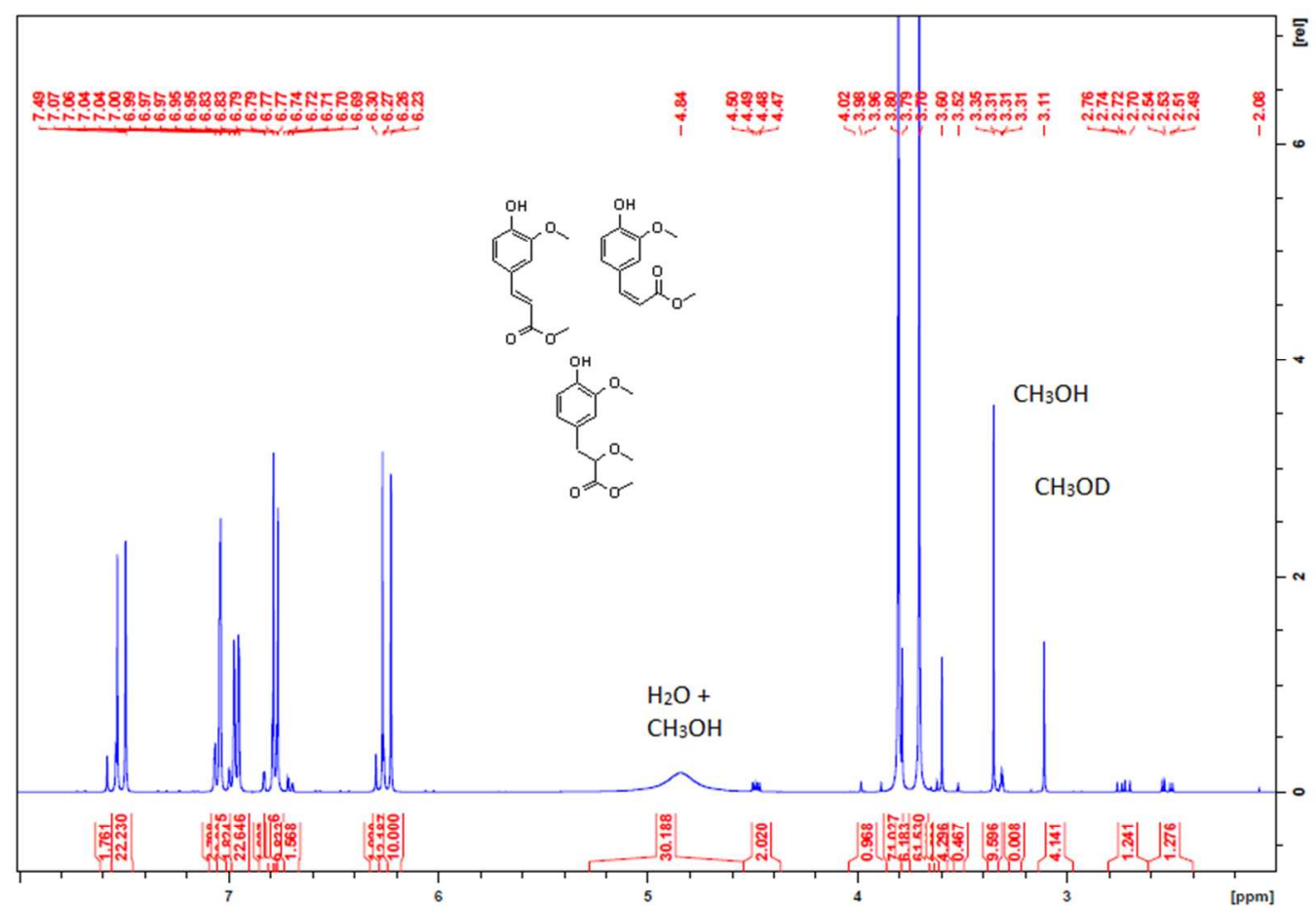

Figure S8: ${ }^{1} \mathrm{H}$ NMR of methyl ferulate

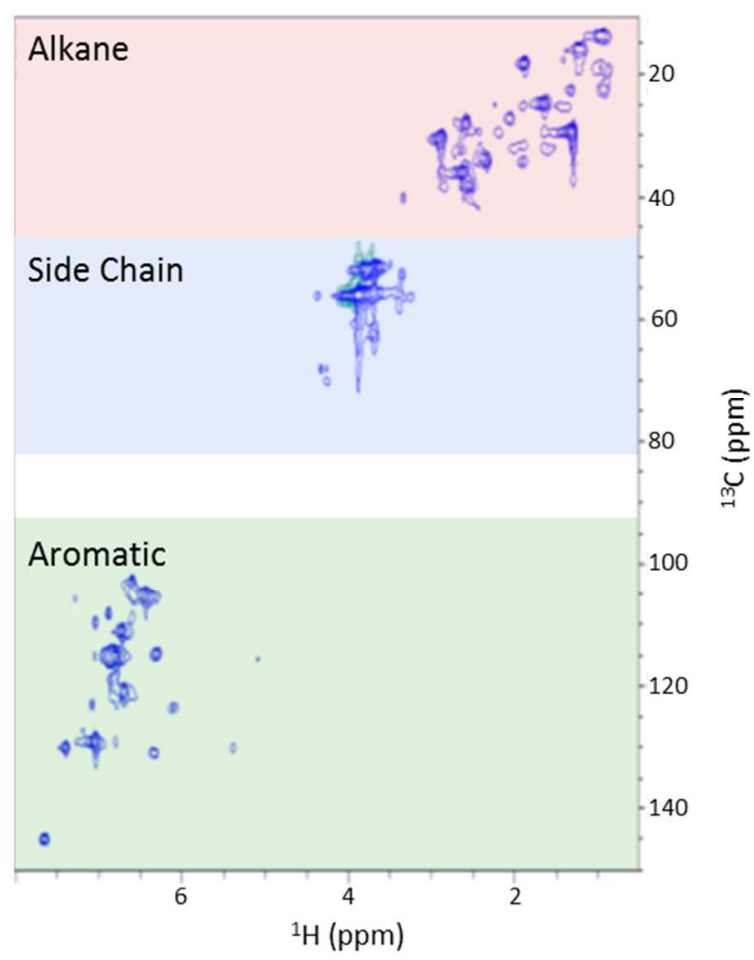

Figure S9: HSQC 2 D-NMR spectrum of lignin oil obtained from an extraction performed at $200^{\circ} \mathrm{C}$ with $\mathrm{Ni} / \mathrm{C}$ for $1 \mathrm{~h}$ 

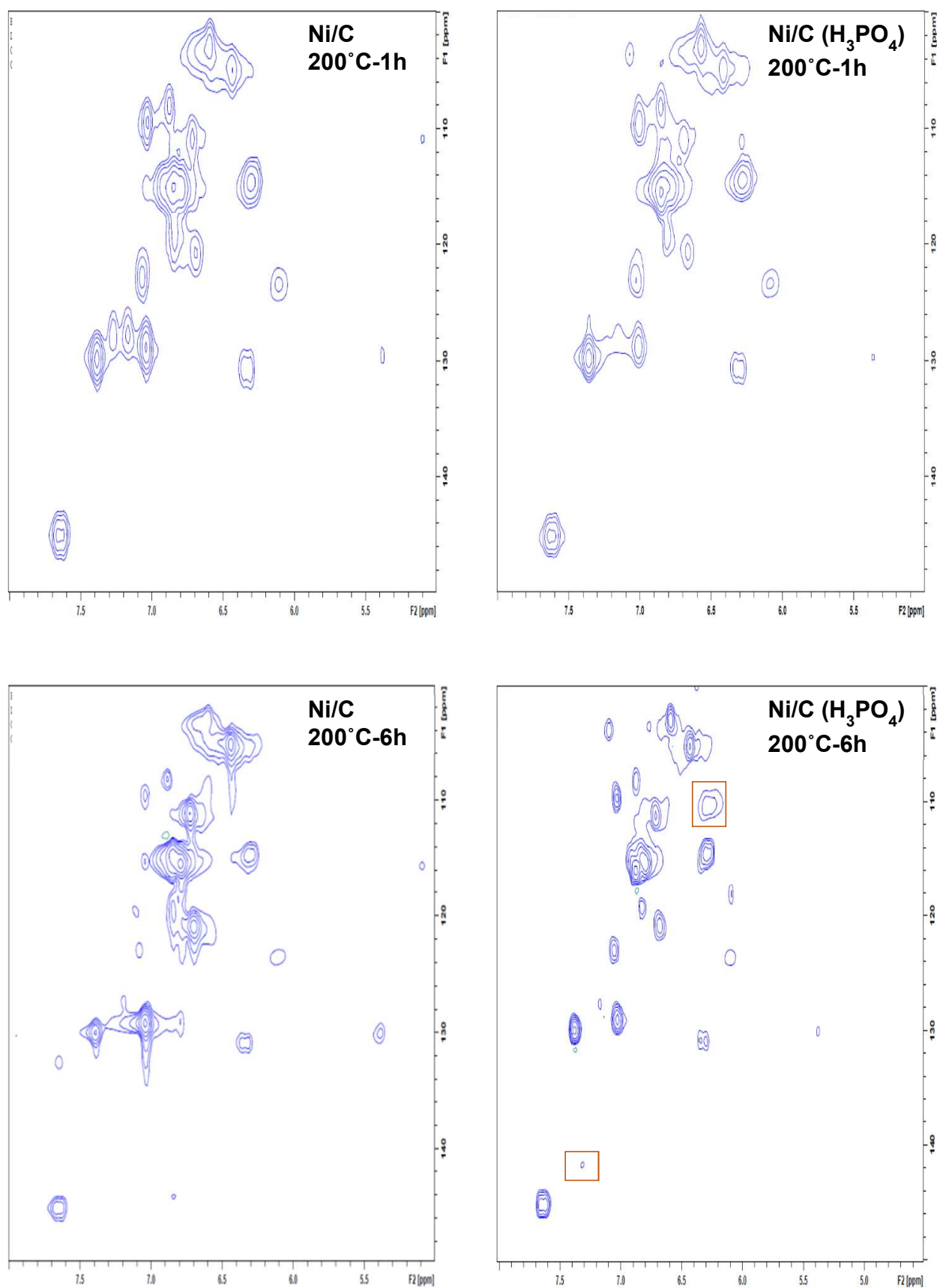

Figure S10: 2D HSQC NMR of lignin oil samples performed with and without acid. The peaks highlighted in red are attributed to furans. 